\title{
Four erupted supernumerary teeth around the maxillary second molar
}

\author{
Kohei Tominaga, Ryo Sasaki [1] , Toshihiro Okamoto
}

Department of Oral and Maxillofacial Surgery, Tokyo Women's Medical University, School of Medicine, Shinjuku-ku, Japan

\section{Correspondence to \\ Dr Ryo Sasaki;}

sasaki.ryo@twmu.ac.jp

Accepted 29 April 2021

\section{DESCRIPTION}

Multiple supernumerary teeth are rare in nonsyndromic patients ${ }^{1}$ and are mainly impacted. ${ }^{2}$ A 26-year-old man presented with four supernumerary teeth around the left maxillary second molar. He was referred to our clinic to remove the left maxillary third molar and four supernumerary teeth because of the bite in the buccal mucosa. He had no significant medical history, except for hay fever, or congenital deformities. Two maxillary central impacted supernumerary teeth were removed at 11 years of age. He had no family history of supernumerary teeth, congenital deformity, or colorectal tumours. However, his younger brother had a congenitally missing tooth. In the intraoral examination, four supernumerary teeth around the left maxillary were noted: one supernumerary tooth on the palate side and three supernumerary teeth on the buccal side (figure 1A). The panoramic radiograph showed no residual deciduous teeth and congenital loss of the permanent teeth. Cone-beam CT showed four supernumerary
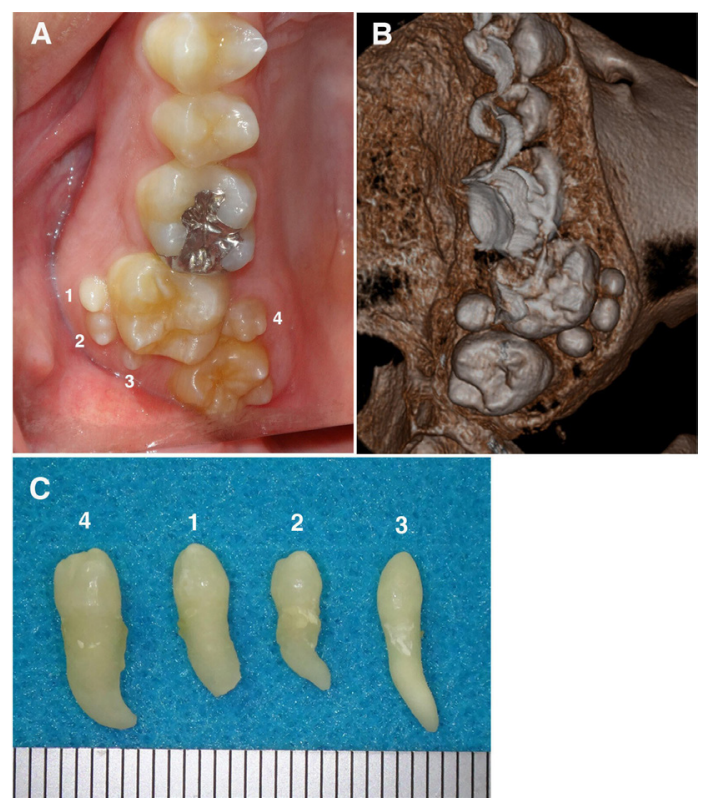

Figure 1 (A) Intraoral photograph (mirror image) showing four supernumerary teeth around the left maxillary second molar. (B) Three-dimensional conebeam CT showing four supernumerary teeth around the left maxillary second molar. (C) A photograph showing four extracted supernumerary teeth. 4 indicates the supernumerary tooth on the palatal side of the left maxillary second molar. 1-3 indicate supernumerary teeth on the buccal side of the left maxillary second molar. 1 is the suspected cause of root fracture. teeth around the left maxillary second molar, and these teeth were single-rooted and thinly curved (figure 1B). All supernumerary teeth and the left maxillary third molar were removed under local anaesthesia. All supernumerary teeth showed microdontia with single roots. Each crown form was different. Conical crowns, incisor-like crowns and crowns with 2 and 4 cusps were noted. The length and width of the supernumerary teeth were 9-13 and 3-5 $\mathrm{mm}$, respectively (figure $1 \mathrm{C}$ ).

The prevalence of supernumerary teeth is approximately $1 \%$ and that of the maxillary central impacted supernumerary tooth is approximately $50 \%$, with the occurrence in one or two teeth. ${ }^{3}$ Multiple supernumerary teeth with four or more teeth occur in cleidocranial dysplasia and Gardner syndrome. ${ }^{4} 5$ Multiple supernumerary teeth are rare in patients without the syndrome. ${ }^{1}$ Reportedly, $25 \%$ of supernumerary teeth erupt, while $75 \%$ are impacted. ${ }^{6}$ In this case, four multiple supernumerary teeth erupted, and these were around one tooth. Although the mechanism of occurrence of the supernumerary teeth is unclear, the phylogenetic theory, tooth germ dichotomy theory, and dental lamina hyperactivity theory have been advocated. ${ }^{78}$ In this case, the dental lamina hyperactivity theory was considered because there was no fusion with the second or third molars, and the developmental time was independent.

\section{Learning points}

Multiple supernumerary teeth with four or more teeth occur in cleidocranial dysplasia and Gardner syndrome.

- Multiple supernumerary teeth are rare in nonsyndromic patients and are mainly impacted.

Acknowledgements The authors thank Prof. Tomohiro Ando for his valuable comments.

Contributors All authors contributed to the design and implementation of the research, to the analysis of the results and to the writing of the manuscript.

Funding The authors have not declared a specific grant for this research from any funding agency in the public, commercial or not-for-profit sectors.

Competing interests None declared.

Patient consent for publication Obtained.

Provenance and peer review Not commissioned; externally peer reviewed.

ORCID iD

Ryo Sasaki http://orcid.org/0000-0003-1821-0471 
Images in...

\section{REFERENCES}

1 Açikgöz A, Açikgöz G, Tunga U, et al. Characteristics and prevalence of non-syndrome multiple supernumerary teeth: a retrospective study. Dentomaxillofac Radiol 2006;35:185-90.

2 Nazif MM, Ruffalo RC, Zullo T. Impacted supernumerary teeth: a survey of 50 cases. J Am Dent Assoc 1983;106:201-4.

3 Stafne EC. Supernumerary teeth. Dental Cosmos 1932;74:653-9.

4 Takahashi K, Togo Y, Saito K, et al. Two non-syndromes cases of multiple supernumerary teeth with different characteristics and a review of the literature. J Oral Maxillofacial Surgery 2016;28:250-4.
5 Shimizu T, Shimizu Y, Miyamoto M, et al. Four supernumerary molars in one maxillary quadrant: a case report. Pediatric Dental Journal 2012;22:198-201.

6 Hattab FN, Yassin OM, Rawashdeh MA. Supernumerary teeth: report of three cases and review of the literature. ASDC J Dent Child 1994;61:382-93.

7 Rallan M, Rallan NS, Goswami M, et al. Surgical management of multiple supernumerary teeth and an impacted maxillary permanent central incisor. BMJ Case Rep 2013;2013:bcr2013009995.

8 Moss ML. Phylogeny and comparative anatomy of oral ectodermal-ectomesenchymal inductive interactions. J Dent Res 1969;48:732-7.

Copyright 2021 BMJ Publishing Group. All rights reserved. For permission to reuse any of this content visit https://www.bmj.com/company/products-services/rights-and-licensing/permissions/

BMJ Case Report Fellows may re-use this article for personal use and teaching without any further permission.

Become a Fellow of BMJ Case Reports today and you can:

- Submit as many cases as you like

- Enjoy fast sympathetic peer review and rapid publication of accepted articles

- Access all the published articles

Re-use any of the published material for personal use and teaching without further permission

\section{Customer Service}

If you have any further queries about your subscription, please contact our customer services team on +44 (0) 2071111105 or via email at support@bmj.com.

Visit casereports.bmj.com for more articles like this and to become a Fellow 